\title{
SEROEPIDEMIOLOGY OF TOXOPLASMOSIS IN HUMANS AND DOGS FROM A SMALL MUNICIPALITY IN PARANA, BRAZIL
}

\section{SOROEPIDEMIOLOGIA DA TOXOPLASMOSE EM HUMANOS E CÃES DE UMA PEQUENA CIDADE NO PARANÁ, BRASIL}

\author{
Aline do Nascimento Benitez ${ }^{1}$ \\ Daniela Dib Gonçalves ${ }^{2}$ \\ Beatriz de Souza Lima Nino ${ }^{1}$ \\ Eloiza Teles Caldart ${ }^{1^{*}}$ \\ Roberta Lemos Freire ${ }^{1}$ \\ Italmar Teodorico Navarro ${ }^{1}$ \\ 'Universidade Estadual de Londrina, Londrina, PR, Brasil. \\ 'Univesidade Paranaense, Umuarama, PR, Brasil. \\ *Corresponding author - eloiza.vet@gmail.com
}

\begin{abstract}
Toxoplasmosis is a worldwide zoonosis with important public health implications. The aims of this study were to determine and identify factors associated to the seroprevalence of anti-Toxoplasma gondii antibodies in humans and dogs from Jataizinho, Parana State, Brazil. Serum samples from 280 humans and 766 dogs, from rural and urban areas, were tested by indirect immunofluorescent antibody test. Positive dilutions were $\geq 1: 16$. Epidemiological informations were obtained through an individual questionnaire and data tabulation was performed using EpiInfo 3.5.3 (CDC, Atlanta). Statistical significance was evaluated by chi-square $\left(\chi^{2}\right)$ or Fisher's exact tests with a $5.0 \%$ significance level. The seroprevalence in humans was $70.00 \%$ (196/280), as follows: $69.08 \%$ $(143 / 207)$ in rural and $72.60 \%$ (53/73) in a slum urban community. The seroprevalence in dogs was $52.35 \%$ (401/766), as follows: $71.74 \%(99 / 138)$ in rural and $48.08 \%(302 / 628)$ in urban area. In rural areas, there was no factor associated to risk of infection. In urban slum community, visualizing more than four rats at home was a factor statistically associated to seropositivity for human toxoplamosis. Infection of urban dogs was associated to age, contact with stray dogs or rodents, and free access to street. The results indicated a similar possibility of contact with Toxoplasma gondii between dogs and humans living in rural or slum urban areas of small municipalities.
\end{abstract}

Keywords: IFAT; prevalence; Toxoplasma gondii; zoonosis.

\section{Resumo}

A toxoplasmose é uma doença de distribuição mundial com importantes implicações em saúde 
pública. Os objetivos deste estudo foram determinar e identificar fatores associados à soroprevalência de anticorpos anti-Toxoplasma gondii em humanos e cães de Jataizinho, Paraná, Brasil. Amostras de soro de 280 humanos e 766 cães, de áreas rural e urbana, foram testadas pela reação de imunofluorescência indireta (RIFI). Foram consideradas positivas diluições $\geq 1: 16$. Informações epidemiológicas foram obtidas por meio de questionário individual e a tabulação dos dados foi realizada com EpiInfo 3.5.3 (CDC, Atlanta). A significância estatística foi avaliada por Chi-quadrado $\left(\chi^{2}\right)$ ou Exato de Fisher com nível de significância de 5,0 \%. A soroprevalência em humanos foi como segue: 70,00\% (196/280), 69,08\% (143/207) em área rural e 72,60\% (53/73) em uma comunidade urbana carente. Em cães, foi 52,35\% (401/766), na área rural 71,74\% (99/138) e na área urbana 48,08\% (302/628). Nas áreas rurais não houve fator estatisticamente associado ao risco de toxoplasmose. $\mathrm{Na}$ área urbana, visualizar mais do que quatro ratos em casa foi fator associado à soropositividade para toxoplasmose em humanos. A soropositividade em cães urbanos apresentou associação à idade, ao contato com cães errantes ou roedores e com acesso livre à rua. Os resultados indicaram semelhante possibilidade de contato com Toxoplasma gondii entre cães e humanos residentes em áreas rurais ou urbanas carentes de pequenos municípios.

Palavras-chave: RIFI. Prevalência. Toxoplasma gondii. Zoonoses.

Received on June $30^{\text {th }}, 2016$

Accepted on January $23^{\text {rd }}, 2017$.

\section{Introduction}

Worldwide, many research groups study the human and animal toxoplasmosis due to its cosmopolitan zoonotic and public health importance ${ }^{(1)}$. The infection by the protozoan Toxoplasma gondii occurs in three distinct ways: ingestion of oocysts in contaminated food or water, ingestion of cysts with bradyzoites in undercooked or raw meat, or transplacental transmission of tachyzoites. In dogs, the chance to contract the disease is exacerbated by its carnivorous behavior and its close contact with the $\operatorname{soil}^{(2)}$. Human toxoplasmosis is associated with socioeconomic and cultural characteristics ${ }^{(3)}$.

The first infection of pregnant women or an immunosuppression condition lead to important clinical manifestations in humans ${ }^{(3)}$. The disease in dogs can rarely present some clinical alteration, and death may occur in a few immunosuppressive conditions ${ }^{(2)}$.

A remote possibility that dogs contribute to the dispersion of the protozoan in the environment as mechanical carriers of oocysts has been suggested ${ }^{(4)}$. However, its close contact with humans and its exposure to the risk of infection allows the use of these animals as sentinels for the presence of the agent at the environment. At Jaguapitã city, Paraná State, a positive correlation across human and dogs population pointed a common route of infection for both ${ }^{(5)}$. At Salvador city, Bahia state, the possibility of infection in humans according to the high prevalence of dogs with anti- $T$. gondii antibodies has been assigned ${ }^{(6)}$.

The absence of seroepidemiological data from human and canine toxoplasmosis in the municipality of Jataizinho, and the possibility to extend the results to similar social and geographical populations 
justified the implementation of this study. The aims of this study were to determine the seroprevalence of anti-Toxoplasma gondii antibodies and identify factors associated to toxoplasmosis in humans and dogs from Jataizinho, Paraná, Brazil.

\section{Material and Methods}

The Ethics Committee for Research Envolving Humans from Universidade Estadual de Londrina (CEP / UEL 319/06 and 121/10) and The Ethics Committee for the Use of Animals from Universidade Estadual de Londrina (CEUA / UEL 58/06 and 32/10) approved this study.

This study was observational and cross-sectional with rural and urban populations of dogs and humans. In urban area, humans were residents of a slum community and pet dogs from total urban area. In rural area, humans and pet dogs were from whole rural area.

Jataizinho is located in the North of Paraná State. With 11,875 inhabitants, $15.58 \%$ of the population from rural area and $12.80 \%$ from urban area have inadequate sanitary conditions, with an income per capita of 0.93 times the minimum wage monthly ${ }^{(7)}$.

At rural area, the study included randomly 63 from 95 registered properties as small farms with cattle at INCRA (Instituto Nacional de Colonização e Reforma Agrária). All humans older than ten years of age were invited to participate in the study, as well as their dogs at over than six months of age.

At urban area, the 513 residences were randomly selected by the software Epi $6.0^{(8)}$, based on the initial population of 3,079 households with pet dogs (ratio inhabitants: households of 4:1 and ratio human: dog of $4: 1)^{(7,9)}, 50 \%$ of expected prevalence, $5 \%$ accuracy, confidence interval of $95 \%$, and Deff 1.5.

The geospatial distribution of the urban interventions into five (A, B, C, D, E) independent districts that correspond to the coverage area of the Basic Health Units (BHUs) in the municipality used the Epidemiological Surveillance and Municipal Health Department as a strategy for the implementation of health programs.

The completed blood collection comprised 766 dogs and 280 humans across urban and rural settings. At the rural area, blood samples were collected from 207 humans and 138 dogs resident at 63 properties. At the urban area, blood samples were collected from 73 humans and 108 dogs from 108 houses in the poorest urban district (slum community) and from 628 dogs from 357 houses in others districts at the urban area.

All the samples were placed in sterile vials, identified, and stored at $-20{ }^{\circ} \mathrm{C}$ until their use. Epidemiological data were obtained by a questionnaire applied to all volunteers (Table 2).

All serum samples were evaluated for IgG antibodies against $T$. gondii by indirect immunofluorescent antibody test (IFAT). Slides were prepared, containing $T$. gondii tachyzoites (strain RH) ${ }^{(10)}$. Serum samples reagent in dilutions higher than 1:16 were considered positive and serially diluted at basis 4; dilutions equal or less than 1:16 were considered negative.

Statistical significance was evaluated by chi-square $\left(\chi^{2}\right)$ or Fisher's exact tests with a $5.0 \%$ significance level by the software EpiInfo 3.4.1. The association degree was determined by odds ratio (CI 95\%). 


\section{Results and Discussion}

In the municipality, $70.00 \%$ (196/280) investigated humans were positive by IFAT; $69.08 \%$ (143/207) individuals from rural area and $72.60 \%$ (53/73) from the urban slum community. In $92.06 \%$ (58/63) rural properties and in $80.00 \%$ (32/40) houses from urban area, at least one volunteer was seroreagent to toxoplasmosis by IFAT.

The seroprevalence of human toxoplasmosis detected in rural areas from Brazil are consistent with this study. In humans, the major source of infection by $T$. gondii is associated with ingestion of oocysts in contaminated food or water, or bradyzoites in raw or undercooked meat or meat products $^{(11)}$. The very similar serologic results detected between rural and urban populations from this study possibly occurred due to their similar cultural and food customs. Other studies on pregnant women $^{(12)}$ and slaughterhouse workers ${ }^{(13)}$ in this city showed the seroprevalence to toxoplasmosis had been affected by educational level, but not among those residences in rural or urban areas. The overall seroprevalence detected $(70.00 \%)$ suggests a large distribution of infection.

The seronegative population of this study $(30.00 \%)$ draws attention to serological monitoring of toxoplasmosis, especially in women at childbearing age in order to avoid severe congenital infection, one of the most important problems due to T. gondii infection. A quarterly serological monitoring in seronegative pregnant women can ensures the diagnosis and provide the early treatment of this infection $^{(1)}$. The results of this study added to others ${ }^{(12,13)}$ indicated that control measures to toxoplasmosis in humans from this small municipality in Paraná must focus on sanitary education for all population, whether urban or rural areas.

Antibodies against T. gondii were detected in 52.35\% (401/766) of dogs; 71.74\% (99/138) in the rural area, and $48.09 \%(302 / 628)$ in the urban area. In the urban area, there was $56.00 \%(98 / 175)$ seroprevalence in slum community and $45.03 \%$ (204/453) in the four districts. At least one dog was positive by IFAT in $87.30 \%$ (55/63) farms and in $57.70 \%$ (206/357) houses from slum community and other four urban areas. The most frequently detected titer was 16 in $170(42.40 \%)$ animals, followed by 64 in 114 (28.40\%), 256 in 92 (23.00\%), 1,024 in $22(5.50 \%)$ and 4,096 in three (0.70\%). Significant differences were detected between dogs from rural and urban area $(\mathrm{p}=0.0000)$ and across farms and houses $(\mathrm{p}<0.0001)$. Dogs from rural area and farms associated to a higher risk of seropositivity to toxoplasmosis. Also, there was statistical significance in the different urban sectors (Table 1). Variables associated with infection risk $(\mathrm{p}<0.05)$ were identified among dogs from the urban area and were not identified among humans and dogs from the rural area (Table 2).

Dogs serve as indicators of environmental contamination with the parasite because they stay in proximity with soil ${ }^{(14)}$. In dogs, the prevalence of anti- $T$. gondii antibodies detected by this study across rural and urban environments was similar to those described in research with stray dogs in Brazil $^{(15-18)}$, and it reflects the cosmopolitan behavior of the parasite ${ }^{(19)}$. Cats are the only animals that can excrete $T$. gondii, which can survive in the environment for months, depending on humidity and temperature ${ }^{(20)}$. In this study, $144 / 628(22.93 \%)$ of pet dogs in urban area were fed only with commercial dog food, which may explain the lower prevalence $(48.48 \%)$ detected among these animals. Higher anti-T.gondii antibodies prevalence in farm dogs $(72.72 \%)$ suggests that eating infected prey is an important source of infection ${ }^{(14,19,21,22)}$. In Brazilian urban dogs, the reported 
prevalence was between $76.40 \%$ in Monte Negro-RO and $18.00 \%$ in Teresina-PI. In Paraná State, prevalences of $54.80 \%$ in Port Figueira, and $50.89 \%$ and $20.60 \%$ in two distinct studies in Londrina ${ }^{(18 \text {, }}$ 23-26) were reported. The titers of antibodies against $T$. gondii detected in these dogs suggest the chronic phase of infection. Although the owners described the dogs participating in this study as healthy, low morbidity in canine toxoplasmosis was previously verified ${ }^{(27)}$; besides, asymptomatic cases are common in chronic infections ${ }^{(28)}$.

Table 1. Distribution of 302 dogs with antibodies against $T$. gondii and 206 houses with sororeagent dogs detected in five different urban districts of Jataizinho, PR, from July to November, 2010

\begin{tabular}{ccccc}
\hline Urban District & $\begin{array}{c}\text { Houses } \\
\text { Positive /Total (\%) }\end{array}$ & $\begin{array}{c}\text { Dogs } \\
\text { Positive/Total (\%) }\end{array}$ & P & OR (CI 95\%) \\
\hline A & $23 / 50(46.00)$ & $33 / 92(35.87)$ & & \\
B & $55 / 63(87.30)$ & $37 / 99(37.37)$ & 0.9479 & $1.07(0.57-2.01)$ \\
C & $31 / 46(67.39)$ & $42 / 99(42.43)$ & 0.4362 & $1.32(0.71-2.46)$ \\
D & $27 / 90(30.00)$ & $92 / 163(56.44)$ & 0.0024 & $2.32(1.32-4.06)$ \\
E* & $70 / 108(64.81)$ & $98 / 175(56.00)$ & 0.0027 & $2.28(1.31-3.96)$ \\
\hline$p=$ Probability; OR= Odds Ratio; CI= Confidence Interval. * Slum community & &
\end{tabular}

Positive dilutions were $\geq 1: 16$ in the indirect immunofluorescent antibody test (IFAT).

Table 2. Variables associated with the risk of infection by $T$. gondii $(\mathrm{p}<0.05)$ and odds ratio in 628 dogs from urban area of Jataizinho, PR, from July to November, 2010

\begin{tabular}{|c|c|c|c|}
\hline Variables & $\begin{array}{c}\text { Number of } \\
\text { Reagent/Total (\%) }\end{array}$ & $p$ & OR (CI 95\%) \\
\hline \multicolumn{4}{|l|}{ Contact with rodents } \\
\hline Yes & $198 / 384(51,56)$ & \multirow{2}{*}{0.0354} & \multirow{2}{*}{$1.97(1,03-1,4)$} \\
\hline No & $104 / 140(74,28)$ & & \\
\hline \multicolumn{4}{|l|}{ Visualize rodents in houses } \\
\hline Yes & $238 / 468(50.85)$ & \multirow{2}{*}{0.0264} & \multirow{2}{*}{$2.21(1.06-1.53)$} \\
\hline No & $64 / 159(40.25)$ & & \\
\hline \multicolumn{4}{|l|}{ Number of rodents visualized } \\
\hline Only 1 & $171 / 359(47.63)$ & & \\
\hline 2 to 4 & $31 / 59(52.54)$ & 0.5762 & $1.83(0.94-3.57)$ \\
\hline More than 4 & $36 / 50(72.00)$ & 0.0029 & $2.73(1.38-5.45)$ \\
\hline \multicolumn{4}{|l|}{ Age } \\
\hline 6 to 12 months & $27 / 88(30.68)$ & & \\
\hline 1 to 8 years & $228 / 445(51.23)$ & 0.0006 & $2.37(1.42-3.99)$ \\
\hline More than 8 years & $47 / 95(49.47)$ & 0.0147 & $2.21(1.16-4.25)$ \\
\hline \multicolumn{4}{|l|}{ Contact with stray dogs } \\
\hline Yes & $171 / 321(53.27)$ & \multirow{2}{*}{0.0099} & \multirow{2}{*}{$2.09(1.11-1.53)$} \\
\hline No & $131 / 307(42.67)$ & & \\
\hline \multicolumn{4}{|l|}{ Access to the street } \\
\hline Yes & $176 / 331(53.20)$ & \multirow{2}{*}{0.0090} & \multirow{2}{*}{$1.54(1.11-2.14)$} \\
\hline No & $126 / 297(42.40)$ & & \\
\hline \multicolumn{4}{|l|}{ Degree of freedom } \\
\hline No access & $22 / 59(12.50)$ & & \\
\hline Parcial/Supervised & $75 / 144(42.60)$ & 0.0781 & $1.83(0.94-3.54)$ \\
\hline Free & $79 / 128(44.90)$ & 0.0031 & $2.71(1.37-5.40)$ \\
\hline
\end{tabular}

$p=$ Probability $; \mathrm{OR}=$ Odds Ratio $; \mathrm{CI}=$ Confidence Interval

Positive dilutions were $\geq 1: 16$ in the indirect immunofluorescent antibody test (IFAT). 
Substantial differences between reagent dogs for $T$. gondii from distinct geographic urban areas were detected among the urban sectors of this research and in other studies in Brazil ${ }^{(6,29)}$. During the visits, deficient sanitation and infrastructure as well as garbage disposal on streets and squares were observed, and these facts could have improved transmission and development of the agent at the environment in districts D and E.

The free access of urban dogs to the street $(p=0.0071)$ and their contact with stray dogs $(p=0.0099)$ interfered in the seropositivity of these animals. Moreover, dogs that spend all day on the streets without human supervision had 2.71 more chances to be infected than those that remained under the owners supervision or that had no access to the street. Although these variables are related, the analysis was performed independently, since there were 49 dogs that although domiciled, had contact with stray dogs in the backyard of their houses. The lower prevalence in dogs at less than one year of age may be associated with shorter length of exposure to sources of T.gondii infection, as referred by several authors worldwide ${ }^{(5,24,27,30-32)}$.

Viewing rodents in groups of more than four individuals in the household $(\mathrm{p}=0.0029)$ and the contact of dogs with rodents $(\mathrm{p}=0.0354)$ are associated to the risk of infection. Despite small rodents may represent a source of infection for dogs by the consumption of rodents infected with cysts of $T$. gondii $(29,30,33,34)$, in the present study, there was no association with hunting rodents.

It is suggested that the control measures adopted can be shared among communities with similar social and geographical aspects.

\section{Conclusions}

The results indicated similar possibility of contact with Toxoplasma gondii in dogs and humans living in rural or slum urban communities in the studied area. It is suggested that the same sanitary education program to control toxoplasmosis could be applied to urban and rural population in small municipalities.

\section{Acknowledgements}

The authors thank the Municipality Health Secretariat of Jataizinho, PR.

\section{References}

1. Mitsuka-Breganó R. Programa de Vigilância em Saúde da Toxoplasmose Gestacional e Congênita: 
elaboração, implantação e avaliação no município de Londrina, Paraná (Doctor's tese). Universidade Estadual de Londrina; 2009.114p. Londrina. $\quad$ Disponível em http://www.bibliotecadigital.uel.br/document/?down=vtls000149504

2. Dubey J, Jones JL. Toxoplasma gondii infection in humans and animals in the United States. International Journal of Parasitology 2008; 38: 1257-1278.

3. Dias RC, Lopes-Mori FMR, Mitsuka-Breganó R, Dias RAF, Tokano DV, Reiche EMV, Freire RL et al Factors associated to infection by Toxoplasma gondii in pregnant women attended in Basic Health Units in the city of Rolândia, Paraná, Brazil. Rev. Inst. Med. Trop. S. Paulo 2011; 53(4): 185-191.

4. Lindsay DS, Dubey JP, Butler JM, Blagburn BL. Mechanical transmission of Toxoplasma gondii oocysts by dogs. Vet. Parasitol. 1997; 73:27-33.

5. Garcia JL, Navarro IT, Ogawa L, Oliveira RC. Seroepidemiology of toxoplasmosis in cats and dogs from rural properties of Jaguapitã country, Parana State, Brazil. Ci. Rural. 1999; 29(1): 99-104.

6. Barbosa MVF, Guimarães JE, Almeida MAO, Gondim LFP, Regis GB. Frequência de anticorpos IgG antiToxoplasma gondii em soros de cães errantes da cidade de Salvador Bahia, Brasil. Braz. J. Vet. Res. Anim. Sci. 2003; 40:457-465.

7. IBGE, 2010: Instituto Brasileiro de Geografia e Estatística: Censo demográfico 2010. Available at: www.ibge.gov.br/cidadesat/topwindow.htm?1 (accessed on 27 December 2011).

8. Dean AG, Dean JA, Coulomerir D, Brendel KA, Smith DC, Burton AH, Dicker RC, et al. Epi Info, Version 6: a word processing, data bases, and statistic program for epidemiology on microcomputers. Center for Diseases Control and Prevention, Atlanta - Georgia, U.S.A. 1994.

9. Alves MCGP, Matos MR, Reichman ML, Domingues MH. Estimation of the dog and cat population in state of São Paulo. Rev. Sau. Pub. 2005; 39(06):891-897.

10. Camargo, ME. Introdução às técnicas de imunofluorescência. Rev. Bras. Patol. Clín. 1973; 10(4):143-171.

11. Mitsuka-Breganó R, Lopes-Mori FMR \& Navarro IT. Toxoplasmose adquirida na gestação e congênita: vigilância em saúde, diagnóstico, tratamento e condutas. $1^{\text {rd }}$ ed. Londrina: EDUEL; 2010.

12. Lopes FMR, Gonçalves DD, dos Reis CR, Breganó RM, Freire RL, de Freitas JC, Navarro IT. Presence of domesticated cats and visual impairment associated to Toxoplasma gondii serum positive children at an elementary school in Jataizinho, State of Paraná, Brazil. Rev. Bras. Parasitol. Vet. 2008; 17; 12 -15.

13. Gonçalves DD, Teles PS, Reis CR, Lopes FMR, Freire RL, Navarro IT, Alves LA et al. Seroepidemiology and occupational and environmental variables for leptospirosis, brucellosis and toxoplasmosis in slaughterhouse workers in the Paraná State, Brazil. Rev. Inst. Med. Trop. S. Paulo. 2006; 48(3): 135-140.

14. Souza SLP, Gennari SM, Yai LEO, D’ Auria SRN, Cardoso SMS, Guimarães JS Jr, Dubey JP. Occurrence of Toxoplasma gondii antibodies in sera from dogs of the urban and rural areas from Brazil. Rev. Bras. Parasitol. Vet. 2003; 12(1): 1-3.

15. Varandas NP, Rached PA, Costa GHN, Souza LM, Castagnolli KC, Costa AJ. Frequence of antibodies for Neospora caninum and Toxoplasma gondii in dogs in northest of São Paulo State. Semina: Ci. Agr. 2001; 22(1): 105-111.

16. Figueredo LA, Danas-Torres F, de Faria EB, Gondim LFP, Simões-Mattos L, Brandão-Filho SP et al. Occurrence of antibodies to Neospora caninum and Toxoplasma gondii in dogs from Pernambuco, Northeast Brazil. Vet. Parasitol. 2008; 157: 9-13.

17. Cabral DD, Silva DAO, Mineo JR, Ferreira FA, Duran FP. Frequency of anti-Toxoplasma gondii antibodies in apparently healthy dogs of the city of Uberlandia-MG. Braz. J. Vet. Parasitol. 1998; 7:87-90. 
18. Araújo DA, Silva AV, Zanetti DF, Silva DR, Correa NAB, Veslasquez LG, Neto AP. Investigação dos fatores associados a infecção pelo Toxoplasma gondii em cães e seres humanos de Porto Filgueira, PR. Vet. e Zootec., Botucatu. 2011; 18(1):98-111.Available at http://aidsinfo.nih.gov/contentfiles/lvguidelines/adult_oi.pdf. Acessado em Novembro de 2016.

19. Moura AB, Souza AP, Sartor AA, Bellato V, Teixeira EB, Pisetta GM, Junior AH. Ocurrence of antibodies and risk factors for infection for Toxoplasma gondii in dogs in the cities of Lages and Balneário Camboriú, Santa Catarina. Rev. Bras. Parasitol. Vet. 2009; 18(3): 52-56.

20. Dubey JP. Toxoplasmosis of Animals and Humans. $2^{\text {nd }}$ ed. CRC Press, Boca Raton, FL; 2010.

21. Navarro IT, Freire RL, Vidotto O, Ogawa L, Kano FS. Estudo comparativo entre soro e plasma na pesquisa de anticorpos anti-Toxoplasma gondii pela técnica de imunofluorescência indireta em cães atendidos no Hospital Veterinário da Universidade Estadual de Londrina - PR, 1996. Semina: Ci. Agr. 1997;18:15-21.

22. Camossi, LG, Faccioli PY, Menozzi BD, Daher SR, Langoni H. Environmental risk factors for canine toxoplasmosis in a deprived district of Botucatu, SP. Brazil. J. Venom. An. Tox. Incl. Trop. Dis. 2008; 14(3): 450-465.

23. Cañón-Franco WA, Bergamaschi DP, Labruna MB, Camargo LMA, Silva JCR, Pinter A, Gennari SM Occurrence of anti-Toxoplasma gondii antibodies in dogs in the urban area of Monte Negro, Rondônia, Brazil. Vet. Res. Commun. 2004; 28:113-118.

24. Lopes MG, Mendonça IL, Fortes KP, Amaku M, Pena HFJ, Gennari SM. Presence of antibodies against Toxoplasma gondii, Neospora caninum and Leishmania infantum in dogs from Piauí. Rev. Bras. Parasitol. Vet. 2011; 20(2): 111-114.

25. Zulpo DL, Leite JHA de C, da Cunha IAL, de Barros LD, Taroda A, Camargo Júnior VE, dos Santos HLEPL et al. Occurrence of anti-Leishmania spp., Neospora caninum and Toxoplasma gondii antibodies in dog sera from Veterinary Hospital from Universidade Estadual de Londrina. Semina: Ci. Agr. 2012; 33(5): 1897-1906.

26. Caldart ET, Constantino C, Pasquali AKS, Benitez A do N, Hamada FN, Dias RCF, Rorato-Nascimento $\mathrm{AM}$ et al. Zoonosis in dogs and cats attended by the Birth Control Project: Toxoplasma gondii, Leishmania spp. and Leptospira spp., serodiagnosis and epidemiology. Semina: Ci. Agr. 2015; 36(1):253-266.

27. Freire RL, Navarro IT, Vidotto O, Tudury EA, Vianna CC. Prevalência de anticorpos anti-Toxoplasma gondii em cães atendidos no hospital veterinario da UEL -PR. Semina, Ci. Agr. 2002,3(1): 66-69.

28. Silva RC, Lima VY, Tanaka EM, Silva AV, Souza LC, Langoni H. Risk factors and presence of antibodies to Toxoplasma gondii in dogs from the coast of São Paulo State, Brazil. Pesq. Vet. Bras. 2010; 30(2): 161-166.

29. Mineo TWP, Silva DAO, Näslund K, Björkman C, Uggla A, Mineo JR. Toxoplasma gondii and Neospora caninum serological status of different canine populations from Uberlândia, Minas Gerais. Arq. Bras. Med. Vet. e Zootec. 2004; 56(3):414-417.

30. Ali CN, Harris JA, Watkins JD, Adesiyun AA. Seroepidemiology of Toxoplasma gondii in dogs in Trinidad and Tobago. Vet. Parasitol. 2003; 113:179-187.

31. Guimarães AM, Rocha CMBM, Oliveira TMFS, Rosado IR, Morais LG, Santos RRD. Factors associated the seropositivity for Babesia, Toxoplasma, Neospora e Leishmania in dogs attended at nine veterinary clinics in the municipality of Lavras, MG. Rev. Bras. Parasitol. Vet. 2009; 18(1): 49-53.

32. Yan C, Fu LL, Yue CL, Tang RX, Liu YS, Lv L, Shi N et al. Stray dogs as indicators of Toxoplasma gondii distributed in the environment: the first report across an urban-rural gradient in China. Parasit Vectors 2012; 5: 5 . 
33. Dubey JP. Advances in the life cycle of Toxoplasma gondii. Int. J. Parasitol. 1998; 28: 1019-1024.

34. Ruffolo BB, Toledo RDS, Martins FDC et al. Isolation and genotyping of Toxoplasma gondii in seronegative urban rats and presence of antibodies in communicating dogs in Brazil. Revista do Instituto de Medicina Tropical de São Paulo, 2016, 58. 